\title{
Alcohol, drugs, and risky sexual behavior are related to HIV infection in female adolescents
}

\section{Álcool, drogas e comportamento sexual de risco estão relacionados à infecção por HIV em mulheres adolescentes}

\author{
Ana Margareth Siqueira Bassols, ${ }^{1}$ Raquel De Boni, ${ }^{1,2}$ Flávio Pechansky ${ }^{1,2}$ \\ ${ }^{1}$ Universidade Federal do Rio Grande do Sul (UFRGS) and Hospital de Clínicas de Porto Alegre (HCPA), Porto Alegre, RS, Brazil \\ ${ }^{2}$ Center for Drug and Alcohol Research, Universidade Federal do Rio Grande do Sul (UFRGS), Porto Alegre, RS, Brazil
}

\begin{abstract}
Objective: To examine associations between risk factors for HIV infection in a sample of young women who sought HIV testing in a city of southern Brazil. Method: Cross-sectional study with a consecutive convenience sample of 258 female adolescents aged 13 to 20 years evaluated in an anonymous testing site for HIV and sexually transmitted diseases in Brazil. Risk behavior for HIV was assessed with the Brazilian version of the Risk Assessment Battery and HIV status was assessed through ELISA (Enzyme Linked Immunosorbent Assay). Results: Overall seropositivity rate was $7.4 \%$. HIV-seropositive patients had significantly more sexual intercourse in exchange for money, higher rates of pregnancy and abortion, as well as earlier sexual debut. In multiple analyses with the inclusion of two composite variables (sex risk and drug risk), only drug risk was associated with positive HIV status (OR $=4.178$; IC 95\% $=1.476$ 11.827). Conclusion: Our findings suggest that high HIV seropositivity among female adolescents seeking HIV testing in Brazil directly reflects the need for effective interventions specifically designed to prevent risk behaviors in order to halt the spread of HIV infection.
\end{abstract}

Descriptors: HIV; Adolescent; Risk-taking; Sexual behavior; Substancerelated disorders

\begin{abstract}
Resumo
Objetivo: Descrever fatores de risco para infeç̧ão pelo HIV numa amostra de adolescentes do sexo feminino que procurou fazer o teste HIV em uma cidade do sul do país. Método: Num estudo transversal, 258 adolescentes do sexo feminino foram avaliadas em relação ao seu estado sorológico para o virus HIV e comportamentos de risco utilizando-se a versão brasileira da escala Risk Assessment Battery. Resultados: A taxa geral de soropositividade foi de 7,4\%. As jovens soropositivas tiveram significativamente mais relaçôes sexuais em troca de dinheiro, história de gravidez e aborto prévio, bem como iniciação sexual mais precoce do que as adolescentes soronegativas. Nas análises multivariadas, com a inclusão de duas variáveis compostas ("risco sexual" e "risco por drogas"), apenas "risco por drogas" esteve associada com o estado sorológico HIV positivo (OR = 4,178 IC 95\% = 1,476-11,827). Conclusão: Nossos achados indicam que a alta soropositividade encontrada nas jovens adolescentes que procuraram testagem evidencia a necessidade de que se desenvolvam medidas de intervenção preventivas especialmente dirigidas para comportamento de risco em mulheres adolescentes para evitar a disseminação da infecção HIV.
\end{abstract}

Descritores: HIV; Adolescente; Comportamento de risco; Comportamento sexual; Transtornos relacionados ao uso de substâncias

\section{Introduction}

Since the identification of the first case of AIDS in Brazil, in 1980, about 474,000 cases of the disease were identified in the country until June, 2007. ${ }^{1}$ In Brazil, AIDS has been characterized as subepidemic, strongly affecting injecting drug users (IDU) and men who have sex with men. In the early 1980s, the affected population also included relevant rates of individuals receiving blood transfusion and blood products (red cells, plasma, platelets, etc.).

More recently, the incidence of AIDS remains high - 19.5 cases per 100,000 inhabitants - mainly due to the persistence of the trend of growth among women. The global human immunodeficiency virus (HIV) pandemic is increasingly becoming a burden for the female population. In the end of 2007, an estimated 15.4 million women were infected with HIV, most of them in their reproductive age. ${ }^{1-3}$ Importantly, young women aged 15 to 24 have a 4 to 7 -fold increased risk of getting infected with HIV when compared with young men of the same age.

After 1998, a trend has been observed toward stability among female cases in the range of 13 to 24 years, while persistent growth

\section{Correspondence}

Ana Margareth Siqueira Bassols

Serviço de Psiquiatria da Infância e Adolescência, Hospital

de Clínicas de Porto Alegre

Rua Ramiro Barcelos, 2350

90035-003 Porto Alegre, RS, Brazil

Phone/Fax number: (+51) 2101-8294

Email: abassols@terra.com.br 
was seen in practically all other age groups. ${ }^{4}$ The incidence of AIDS among women aged between 13 and 19 years has increased from 3.7 cases per 100,000 women in 1994-1998 to 4.5 cases per 100,000 in 2004-2005 in southern Brazil. The inverse relationship is observed among adolescents ( 13 to 19 years old). The male/ female ratio of AIDS cases for all ages has varied from 40/1 in 1983 to $1.5 / 1$ in 2007 , clearly showing a change in the epidemiological profile of AIDS in Brazil. ${ }^{4}$

Especially for youngsters, the UNAIDS/WHO report emphasizes the need for preventive efforts, since recent data from several countries have demonstrated an increase in the incidence of risky behaviors, low frequency of condom use, and higher rates of sexually transmitted diseases (STDs) in this specific group. ${ }^{2}$ Previous studies have not found significant differences between HIV prevalence rates in men and women, although risk factors for infection were different between genders: Silva-Lima et al. compared seropositivity in 420 drug users (IDU and non-IDU) and reported that men were more exposed to risk due to the use of injecting drugs, while women exposed themselves through sexual relations with partners who were IDU and potentially infected. ${ }^{5}$ In 2005, Pechansky et al. showed that men and women in the same city presented no differences in regard to the prevalence of HIV, but risk behaviors did differ across genders: women had a higher chance of having heterosexual intercourse without the use of condoms as well as intercourse with IDU, while men presented a higher chance of having homosexual intercourse without the use of condoms or sexual intercourse with sex professionals. ${ }^{6}$

Marijuana, cocaine, and other drugs have been associated with a higher rate of sexual relations, multiple partners, and less frequent use of condoms. ${ }^{7}$ Donenberg and Pao, in a review of 10 years of the English language literature focused on child and adolescent risk factors associated with HIV/AIDS, showed the significant implications of the infection for mental health. ${ }^{8}$

HIV testing is the first step toward treatment, care, and prevention; however, the use of testing in a universal scale is limited. Even in developed countries, about $20 \%$ to $30 \%$ of seropositive individuals were unaware that they were infected in 2007. ${ }^{9}$

Research indicates that gender powerfully shapes attitudes toward universal testing. Men tend to underestimate their risk of being infected with HIV more frequently than women, despite reporting more risky behaviors, and women have more fears related to testing. ${ }^{10}$

Murphy et al. described testing patterns among high-risk HIVinfected $(\mathrm{n}=246)$ and non-infected $(\mathrm{n}=141)$ adolescents in sites throughout the United States (the REACH study). ${ }^{11}$ They were asked about the number of times they had been tested for HIV, the site at which testing was performed, and reasons for testing. The majority of participants reported being influenced to get tested by health care providers ( $53.1 \%$ of the HIV-infected group and $66.1 \%$ of the non-infected group). Female participants were more likely to have used a confidential or anonymous site for their most recent test compared with male participants $(73.5 \%$ and $67.5 \%$, respectively). In the HIV-infected group, feeling sick was the only factor associated with number of tests. In the non-infected group, having more male partners, marijuana use in the past three months, Caucasian race, and having had same-gender partners over the lifetime (males only) were associated with number of tests.

The main objective of this study was to examine associations between risk factors for HIV infection in a sample of young women seeking HIV testing at a public health center in a city of southern Brazil. The primary focus of this article was to determine which risk factors are most relevant to adolescent female reproductive health in our country.

\section{Method \\ 1. Sample}

A consecutive sample of female adolescents aged 13 to 20 years, interviewed over one year in an anonymous testing site for HIV and STDs in the city of Porto Alegre (Brazil), was included in this study. The only exclusion criteria were clinically verified cognitive impairment and altered state of consciousness, which could hinder the interview, and involuntary attendance to the center (e.g., court decision). The sample was not randomized.

According to information from the testing site, about 1,000 adolescents (13 to 20 years old) seek for anonymous testing each year. Using the convenience method of approaching each potential subject when interviewers were available at the clinic ( 5 days a week, twice a day, for one year, between 10/30/2000 and $10 / 30 / 2001$ ), we managed to enroll 388 subjects of both genders. Participants were informed of the study objectives and completed the questionnaires anonymously. The study was conducted with the adolescents' consent - only those who accepted to participate completed the forms. The study was approved by the Ethics Committee and Institutional Review Board of the Hospital de Clínicas de Porto Alegre, under grant \# 00239.

\section{Design}

This was a cross-sectional study. Independent variables were risk behaviors for HIV infection (sexual risk behaviors and drug use risk behaviors). HIV status was the dependent variable.

\section{Procedures and instruments}

Data were collected by trained interviewers who were blind in respect to the respondents' serostatus. Standard pre-test counseling data were collected by the center's permanent staff. Adolescents completed the questionnaires individually. The interviewers were trained in a pilot study with the collection of data from 19 cases, which were excluded from the final analyses. These pilot cases were used to calibrate the parameters for data collection and for the development of the database.

Instruments used included:

1) Risk Assessment Battery (RAB). ${ }^{12}$ The RAB is a self-applied questionnaire translated and validated into Brazilian Portuguese. ${ }^{6,13}$ It assesses drug and sexual behaviors throughout life, over the previous six months, and during the month prior to data collection, 
as well as basic demographic data. The instrument comprises 38 questions. Questions about the age at sexual initiation, pregnancy, and/or previous abortions were added to the RAB.

2) Enzyme Linked Immunosorbent Assay (ELISA) and confirmatory tests to evaluate HIV serostatus. All blood samples were tested using two ELISA assays with different antigens. The exams with positive, indeterminate or discordant results were confirmed using the Indirect Immunofluorescence technique (IFI). Indeterminate immunofluorescence was confirmed with the Western Blot test.

The database was subjected to systematic internal analyses, where questionnaires were individually checked, retyped, and compared by an external observer.

\section{Data analyses}

Quantitative data were described in terms of means and standard deviations, and qualitative data in terms of absolute and percentile frequency. Odds ratios (OR) were calculated with their respective confidence intervals of $95 \%$ and their significance was determined with the Chi-square test. Exact chi-square test was used for low frequencies. Relations among quantitative data were evaluated using Student's $t$ test. All tests were two-tailed. The level of significance was set at 5\% and the data were analyzed using SPSS version 11.0.

After bivariate analyses, we performed a multivariable logistic regression analysis. To avoid excessive testing (type I error) and collinearity, we entered two composites: SEX-RISK (based on all individual variables over the lifetime that were associated with positive HIV status in the bivariate analyses with $\mathrm{p}<0.2$ : sexual relations with male partners without condom, sexual relation with an IDU partner and money in exchange for sexual relation and sexual relation with a possible HIV positive partner and sexual debut $<12$ years old and pregnancy and abortion and not using condom in sexual relations) and DRUG-RISK (based on the following individual variables: illicit drug use and having been in drug-using/drug-selling places).

\section{Results}

The sample here described comprised 258 female adolescents*. The overall prevalence of HIV-positive status was $7.4 \%$. The adolescents presented low education and income. No significant differences were detected between HIV positive and negative subjects regarding demographic variables (education, age, family income, marital status, and employment) (see Table 1).

With regard to sexual risk factors throughout life, positive HIV status was significantly associated with sexual initiation before age $12(\mathrm{p}<0.001)$, history of pregnancy $(\mathrm{p}=0.004)$, previous abortion $(\mathrm{p}<0.001)$, and receiving money in exchange for sex $(\mathrm{p}=0.017)$. Other variables not significantly associated with HIV seropositivity but included in the SEX-RISK composite for the multivariate analyses $(\mathrm{p}<0.2)$ were sexual relations with IDU partners and never using condoms. Infrequent condom use was high in both groups (77.9\%). As for risky sexual practices in the six months prior to the study, female adolescents who reported having received money for sex showed a higher association with seropositivity $(p<0.04)$, the same happening with those who had sexual relations with a possible seropositive partner $(\mathrm{p}<0.001)$ (Table 2$)$.

Table 1 - Demographic data

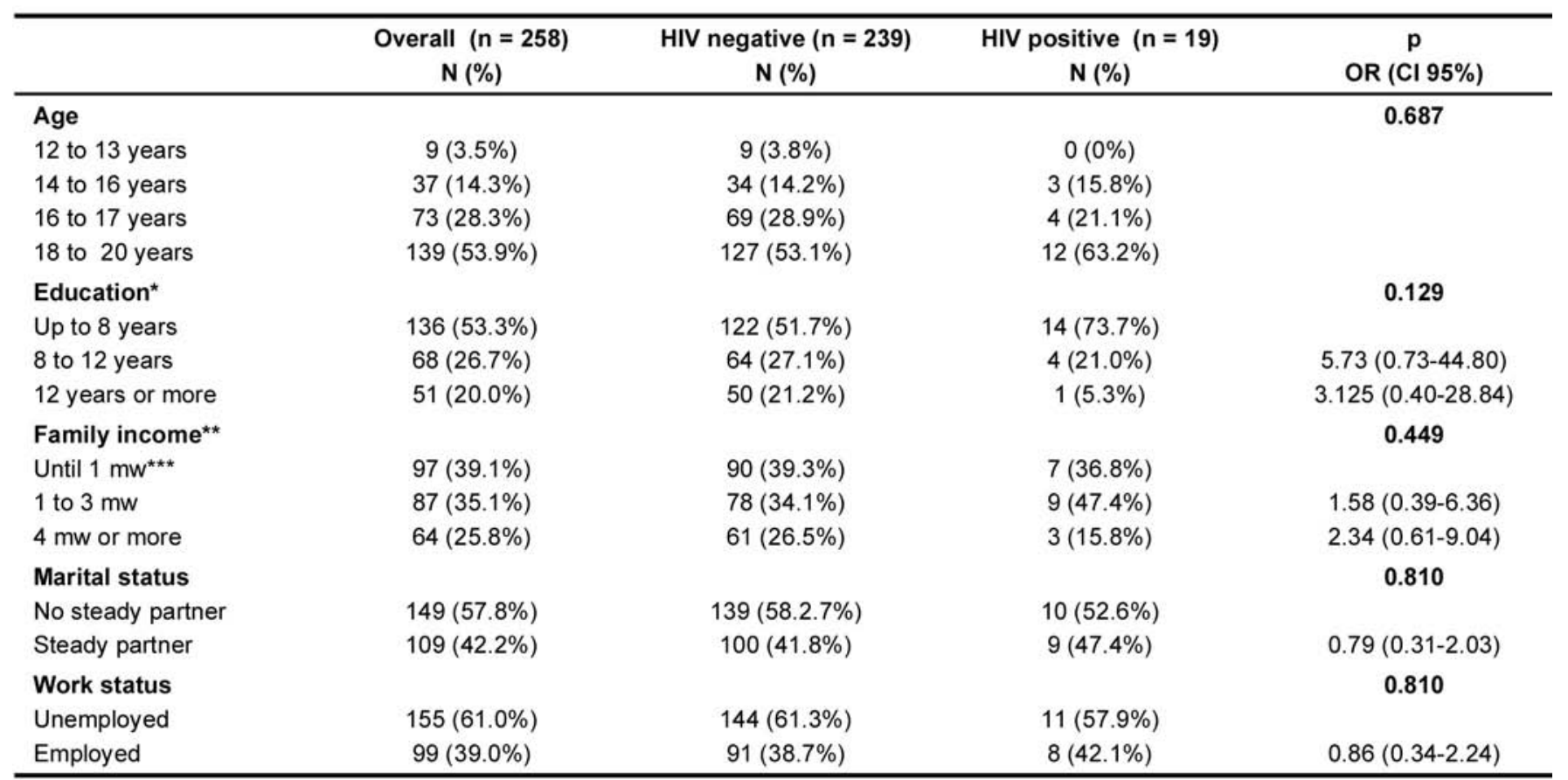

${ }^{\star} n=255 ;{ }^{* \star} n=248 ;{ }^{* \star \star}$ mw: minimum wage (about U\$ 130)

* The results of all sample are published in Bassols AMS, Santos RA, Rohde LA, Pechansky F. Exposure to HIV in Brazilian adolescents: the impact of psychiatric symptomatology. Eur Child Adolesc Psychiatry. 2007;16(4):236-42. 


\begin{tabular}{|c|c|c|c|c|}
\hline & $\begin{array}{c}\text { Overall }(n=258) \\
N(\%)\end{array}$ & $\begin{array}{c}\text { HIV negative }(n=239) \\
N(\%)\end{array}$ & $\begin{array}{c}\text { HIV positive }(n=19) \\
N(\%)\end{array}$ & $\begin{array}{c}p \\
\text { OR }(\mathrm{Cl} 95 \%)\end{array}$ \\
\hline Sex without condom & & & & 0.491 \\
\hline Yes & $201(77.9 \%)$ & $185(77.4 \%)$ & $16(84.2 \%)$ & $1.56(0.44-5.54)$ \\
\hline Sex for money & & & & 0.017 \\
\hline Yes & $12(4.7 \%)$ & $9(3.8 \%)$ & $3(15.8 \%)$ & $4.9(1.18-19.46)$ \\
\hline Sex with IDU & & & & 0.541 \\
\hline Yes & $10(3.9 \%)$ & $9(3.8 \%)$ & $1(5.3 \%)$ & $1.42(0.17-11.84)$ \\
\hline Male partners in last 6 months & & & & $>0.999$ \\
\hline 0 & $16(6.2 \%)$ & $15(6.3 \%)$ & $1(5.3 \%)$ & \\
\hline 1 & $153(59.3 \%)$ & $142(59.4 \%)$ & $11(57.9 \%)$ & \\
\hline 2 or more & $89(34.5 \%)$ & $82(34.3 \%)$ & $7(36.8 \%)$ & \\
\hline Sex for drugs & & & & 0.175 \\
\hline Yes & $4(1.6 \%)$ & $3(1.3 \%)$ & $1(5.3 \%)$ & $4.35(0.43-43.99)$ \\
\hline $\begin{array}{l}\text { Sex with possible HIV positive } \\
\text { in the last } 6 \text { months }\end{array}$ & & & & $<0.001$ \\
\hline At least once & $225(87.2 \%)$ & $22(9.2 \%)$ & $8(42.1 \%)$ & \\
\hline Never & $33(12.8 \%)$ & $217(90.8 \%)$ & $11(57.9 \%)$ & $13.56(4.93-37.27)$ \\
\hline Concern about being infected & & & & 0.085 \\
\hline Anytime & $190(73.9 \%)$ & $173(72.7 \%)$ & $17(89.5 \%)$ & $3.19(0.72-14.20)$ \\
\hline Never & $67(26.1 \%)$ & $65(27.3 \%)$ & $2(10.5 \%)$ & \\
\hline $\begin{array}{l}\text { Concern about possible } \\
\text { infection in the future }\end{array}$ & & & & 0.931 \\
\hline Anytime & $197(77.0 \%)$ & $183(76.9 \%)$ & $14(73.7 \%)$ & $1.05(0.33-3.28)$ \\
\hline Never & $59(23.0 \%)$ & $55(23.1 \%)$ & $4(21.0 \%)$ & \\
\hline $\begin{array}{l}\text { Concern about transmitting } \\
\text { HIV }\end{array}$ & & & & 0.56 \\
\hline Anytime & $147(57.4 \%)$ & $132(55.7 \%)$ & $15(78.9 \%)$ & $2.98(0.96-9.26)$ \\
\hline Never & $109(42.6 \%)$ & $105(44.3 \%)$ & $4(21.0 \%)$ & \\
\hline Sexual debut & & & & $<0.001$ \\
\hline Before 12 years & $14(8.0 \%)$ & $10(6.1 \%)$ & $4(21.0 \%)$ & $10.28(2.487-42.37)$ \\
\hline 12 years or more & $160(92.0 \%)$ & $154(93.9 \%)$ & $6(31.6 \%)$ & \\
\hline Pregnancy & & & & 0.004 \\
\hline 1 or more & $121(46.9 \%)$ & $106(44.4 \%)$ & $15(78.9 \%)$ & $4.70(1.51-14.57)$ \\
\hline None & $137(53.1 \%)$ & $133(55.6 \%)$ & $4(21.0 \%)$ & \\
\hline Pregnancy Number & & & & $<0.001$ \\
\hline None & $137(53.1 \%)$ & $133(55.6 \%)$ & $4(21.0 \%)$ & \\
\hline 1 & $79(30.6 \%)$ & $74(31.0 \%)$ & $5(26.3 \%)$ & \\
\hline 2 & $32(12.4 \%)$ & $26(10.9 \%)$ & $6(31.6 \%)$ & \\
\hline 3 & $10(3.9 \%)$ & $6(2.5 \%)$ & $4(21.0 \%)$ & \\
\hline Abortion & & & & 0.001 \\
\hline Yes & $39(15.2 \%)$ & $31(13.0 \%)$ & $8(42.1 \%)$ & $4.85(1.81-12.99)$ \\
\hline
\end{tabular}

The overall prevalence of drug use in the month prior to the data collection was high in both groups (Table 3). The most frequently reported drugs used were alcohol, marijuana, snorted cocaine, and inhalants. HIV-positive females used significantly more illicit drugs $(p=0.002)$. Specifically, recent marijuana $(p=0.001)$, amphetamines $(p=0.005)$, snorted cocaine $(p=0.001)$, and solvent use $(\mathrm{p}<0.001)$ were significantly higher in HIV-positive female adolescents. Attendance to drug-using/selling places was also significantly associated with seropositive status $(\mathrm{p}=0.001)$.

Findings from multivariate logistic regression analyses can be found in Table 4. When education and the two composites (SEX-
RISK and DRUG-RISK) were included in the final model, the DRUG-RISK composite was the only one that reached statistical significance after regression $(\mathrm{p}=0.007)$.

\section{Discussion}

It is important to emphasize that this sample was composed of young people with low income and education, which represents a high risk for HIV infection, as reported in the literature. ${ }^{14}$ Besides, voluntary HIV testing is uncommon among young people, and Murphy et al. demonstrated that one of the main reasons for HIV testing among infected or at-risk adolescents was the concern 
of having been infected during sexual intercourse. ${ }^{11}$ The high seroprevalence found in this sample may be due to the fact that a significant fraction of it $(73.9 \%)$ reported concern about having been infected, which may have motivated their visit to a testing site. However, the UNAIDS/WHO (2008) reported an HIV prevalence of $0.6 \%$ for women aged between 15 and 24 years in 2007. ${ }^{2}$ The latest AIDS numbers confirm the increasing rates of infected females year after year, with younger women as the group in which the epidemic has spread the most in the country.

Risky sexual behaviors were marginally associated with positive HIV status in multivariate analyses. Among these behaviors, early sexual initiation seems to be a relevant factor for HIV infection. Most teenagers reported sexual debut between 12 and 16, and those who started before age 12 were at an even greater risk for HIV infection. Delayed sexual initiation could bring an extra advantage to the protection of adolescents from STDs and unwanted pregnancy. Whaley suggests that this approach to both AIDS and unwanted pregnancy would favor the care delivered to female adolescents with regard to these aspects..$^{15}$ This approach would be sensible in this subgroup, since in this sample $75.4 \%$ of the adolescents had their sexual debut before 16 years of age. A major goal in many countries is to delay the age at which young people have their first sexual intercourse and to discourage premarital sexual activity, since these strategies reduce their exposure to HIV. Our findings are supported by evidence from the UNAIDS ${ }^{16}$ that having sex at a later age reduces the susceptibility to infection per act of sex, at least in women.
Many young people still lack accurate, complete information about preventing exposure to the virus ${ }^{17}$ and survey data from 64 countries indicate that only $40 \%$ of males and $38 \%$ of females aged 15-24 years had accurate and comprehensive knowledge about HIV and preventive measures (UNGASS indicator 13). Young females are notably less likely than young males to have accurate and comprehensive knowledge about HIV. Whereas more than $70 \%$ of men are aware that condoms can protect against HIV exposure, only $55 \%$ of young women cite condom use as an effective prevention strategy. ${ }^{17}$

The early beginning of sexual activity may be also associated with sexual abuse and violence, which increases the risk of HIV infection. Wingood et al. state that young women who have suffered gender-based violence have been relatively neglected by HIV prevention programs. ${ }^{18}$ Childhood maltreatment has been associated with risky sexual practices in adolescence, including more partners, less condom use, more frequent intercourse, and less HIV testing. In many cases, drug use mediates this relationship. ${ }^{15}$

In a Brazilian survey conducted in 1998 and 2005 with a representative sample of 5,040 men and women aged 16 to 65 years, the overall prevalence of sexual violence committed by an intimate partner was $8.6 \%$, with a higher prevalence of female victims (11.8\% vs. $5.1 \%)$. Lower income and education predicted greater violence. Different situations including work, condom use in the first sexual intercourse, age, and number of partners over the past five years differed significantly for women, but not for

Table 3 - Drug use and HIV infection

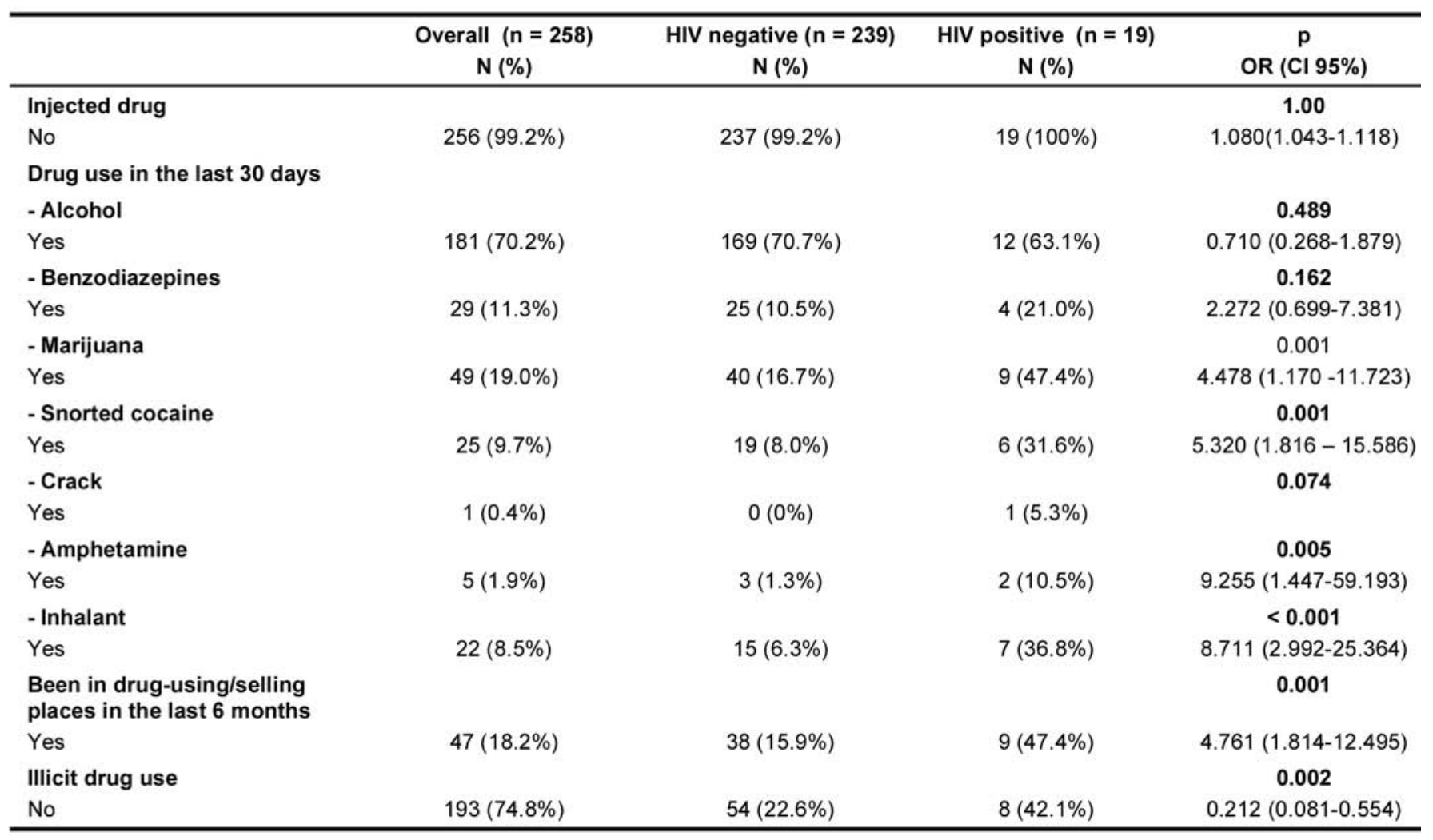




\begin{tabular}{|c|c|c|c|c|}
\hline & $\begin{array}{c}\text { Overall }(n=258) \\
N(\%)\end{array}$ & $\begin{array}{c}\text { HIV negative ( } n=239) \\
N(\%)\end{array}$ & $\begin{array}{c}\text { HIV positive }(n=19) \\
\text { N (\%) }\end{array}$ & $\begin{array}{c}p \\
\text { OR }(\mathrm{Cl} 95 \%)\end{array}$ \\
\hline Education & & & & 0.46 \\
\hline Up to 8 years & $136(53.3 \%)$ & $122(51.0 \%)$ & $14(73.7 \%)$ & $3.45(0.42-28.42)$ \\
\hline 8 to 12 years & $68(26.7 \%)$ & $64(26.78 \%)$ & $4(21.0 \%)$ & $2.33(0.24-22.43)$ \\
\hline SEX-RISK* & ${ }^{*} n=257$ & & & 0.56 \\
\hline Yes & $178(69.26 \%)$ & $161(67.4 \%)$ & $17(89.5 \%)$ & $2.62(0.56-12.27)$ \\
\hline No & $79(30.73 \%)$ & $77(32.2 \%)$ & $2(10.5 \%)$ & \\
\hline DRUG-RISK ${ }^{\star \star}$ & & & & 0.007 \\
\hline Yes & $83(32.18 \%)$ & $70(29.3 \%)$ & $13(68.4 \%)$ & $4.18(1.47-11.83)$ \\
\hline No & $175(67.82 \%)$ & $169(70.7 \%)$ & $6(31.6 \%)$ & \\
\hline Blood transfusion & & & & 0.086 \\
\hline Yes & $13(5.0 \%)$ & $9(3.8 \%)$ & $4(21.0 \%)$ & $3.40(0.84-13.86)$ \\
\hline No & $245(95.0 \%)$ & $230(96.2 \%)$ & $15(78.9 \%)$ & \\
\hline
\end{tabular}

* SEX-RISK (sexual relation with male partners without condom + sexual relation with an IDU partner + money in exchange for sexual relation + sexual relation with a possible HIV positive partner + sexual debut $<12$ years old + pregnancy + abortion + never used condom in sexual relation).

** DRUG-RISK (illicit drug use + been in drug-using/drug-selling places; those presenting a $p<0.2$ in bivariate analyses).

men. Sexual violence is an important factor to be considered in the feminization of the affected population when considering the AIDS epidemic. It confirms the high magnitude of sexual violence and the burden placed on females. ${ }^{19,20}$

In this study, data on sexual abuse and violence were not collected, and thus we can only infer that this association might be present, with further research being necessary to address this topic. Almost half of HIV-positive adolescents had a history of previous abortion, and this could also be associated with violence and early sexual debut. In Brazil this represents a dangerous situation, since abortion is not legal and women must resort to illegal clinics with no safety in this kind of procedure, which contributes for abortion to be an important cause of mortality among women. ${ }^{21}$ Moreover, our data are in accordance with the findings of Olinto et al., suggesting that they are the main predictors of induced abortion between adolescents with low economic level and low level of education. ${ }^{22}$

The infrequent use of condoms and carelessness in preventing pregnancy detected in our sample is also in agreement with reports from other studies. ${ }^{23,24}$ Almost $80 \%$ of the adolescents reported having had sex without condoms. Despite nationwide media campaigns, information is not used by adolescents, including those who perceive themselves as belonging to a high-risk group. It is possible to speculate that the lack of education and the altered perception generated by drug use makes these subjects feel invulnerable. Attention to HIV education and prevention in adolescents has been inappropriately limited and strategies to encourage safer behaviors are urgently needed.

Substance use was highly prevalent in the sample. The use of marijuana, cocaine, and benzodiazepines was twice as common as compared with the use of these substances by Brazilian girls in the same age group. ${ }^{25}$ The use of injected cocaine, a well known risk behavior for HIV, ${ }^{26-28}$ was low. This is in accordance with the findings of previous studies conducted by our group demonstrating a low prevalence of IDU in women from Porto Alegre. ${ }^{6,29}$ In the multivariable logistic regression analyses, only drug score was significantly associated with HIV infection. Substance use reduces the perception of risk and the ability to negotiate safe sex and can thus mediate HIV infection. ${ }^{30}$ Additionally, low-income women in need of drugs are more likely to trade sex for drugs and money.

\section{Limitations}

The findings of this study should be understood without disregarding two identified methodological limitations. First, the generalization of our findings to other geographic or socioeconomic groups is restricted due to the convenience sampling design: the sample was selected at a free testing site, which may have generated a higher rate of seropositivity as opposed to non-clinical samples. Second, for logistic reasons it was not possible to test the subjects for IQ. Finally, the small sample size of HIV-positive adolescents might have prevented the detection of some clinically relevant associations.

\section{Conclusion}

Health professionals dealing with policies for HIV prevention in young people from southern Brazil must necessarily take into account differences across genders. Given the increasing number of new infections among adolescent females around the world, a new generation of interventions is needed, considering the specific characteristics of infection in this population. Interventions available today are limited by their focus on single behaviors that have little epidemiologic significance - such as condom use - and insufficient testing among most vulnerable females. Maybe the next generation of interventions should focus on sexual risk networks in which drug use and other high-risk behaviors are prevalent. Future research should include formative and observational studies to inform new intervention trials that are 
able to reach the highest-risk female youth. The evidence presented does not only demonstrate the relationship between drugs and risky sex, already identified by our group 10 years ago, ${ }^{31-36}$ but the precociousness of this association in low-age females. The alert is for earliness.

Our findings indicate that health professionals, especially those that deal with drug abuse/dependence, should be an active part of the team in charge of developing and implementing preventive strategies against HIV infection in female adolescents.
In addition, longitudinal studies are needed to identify the specific roles of risky sexual behaviors and drug use in the pathway leading to HIV infection during adolescence.

\section{Acknowledgements}

The authors wish to thank Vania Gomes Hirakata for performing analyses and database management.

This study was supported by the Fund for Research Development of the Hospital de Clínicas of Porto Alegre under grant \# 00239.

\section{Disclosures}

\begin{tabular}{|c|c|c|c|c|c|c|c|}
\hline $\begin{array}{l}\text { Writing group } \\
\text { member }\end{array}$ & Employment & $\begin{array}{l}\text { Research } \\
\text { grant }^{1}\end{array}$ & $\begin{array}{l}\text { Other research grant or } \\
\text { medical continuous } \\
\text { education }^{2}\end{array}$ & $\begin{array}{l}\text { Speaker's } \\
\text { honoraria }\end{array}$ & $\begin{array}{c}\text { Ownership } \\
\text { interest }\end{array}$ & $\begin{array}{l}\text { Consultant/ } \\
\text { Advisory } \\
\text { board }\end{array}$ & Other $^{3}$ \\
\hline $\begin{array}{l}\text { Ana Margareth } \\
\text { Siqueira Bassols }\end{array}$ & $\begin{array}{c}\text { UFRGS } \\
\text { HCPA }\end{array}$ & FIPE/HCPA & - & - & - & - & - \\
\hline Raquel De Boni & $\begin{array}{c}\text { Centro de } \\
\text { Pesquisa em } \\
\text { Álcool e Drogas } \\
\text { da UFRGS }\end{array}$ & SENAD*** & - & - & - & - & - \\
\hline Flávio Pechansky & $\begin{array}{c}\text { Centro de } \\
\text { Pesquisa em } \\
\text { Álcool e Drogas } \\
\text { da UFRGS }\end{array}$ & $\begin{array}{l}\text { SENAD***} \\
\text { University } \\
\text { of } \\
\text { Kentucky* }\end{array}$ & $\mathrm{CNPq}$ & - & - & - & - \\
\hline \multicolumn{8}{|c|}{$\begin{array}{l}{ }^{*} \text { Modest } \\
{ }^{* *} \text { Significant } \\
\text { *** Significant: Amounts given to the author's institution or to a colleague for research in which the author has participation, not directly to the } \\
\text { author. } \\
\text { Note: UFRGS = Universidade Federal do Rio Grande do Sul; HCPA = Hospital de Clínicas de Porto Alegre; FIPE/HCPA = Fundo de Incentivo a } \\
\text { Pesquisa e Eventos do Hospital de Clinicas de Porto Alegre; SENAD = Secretaria Nacional Antidrogas; CNPq = Conselho Nacional de } \\
\text { Desenvolvimento Cientifico e Tecnológico. } \\
\text { For more information, see Instructions for Authors. }\end{array}$} \\
\hline
\end{tabular}

\section{References}

1. UNAIDS/WHO. Epidemiological Facts Sheets on HIV and AIDS, 2008 Update, December 2008. [cited 2010 jun 28]. Available from:http://apps.who. int/globalatlas/predefinedReports/EFS2008/full/EFS2008_HT.pdf

2. UNAIDS/WHO. AIDS Epidemic Update. December 2007. [cited 2010 jun 28]. Available from:http;// www.unaids.org/en/KnowledgeCentre/HIVData/ EpiUpdate/EpiUpdArchive/2007/default.asp

3. Heikinheimo O, Lähteenmäki P. Contraception and HIV infection in women. Hum Reprod Update. 2009;15(2):165-76.

4. Ministério da Saúde. Secretaria de Vigilância em Saúde. Programa Nacional de DST e Aids. Boletim Epidemiológico AIDS e DST: Ano V, no 1. Brasília: Ministério da Saúde; 2008.

5. Silva-Lima AFB, Genro VK, Pechansky F. Soropositividade para HIV entre usuários de drogas em Porto Alegre: uma comparação entre usuários e não-usuários de drogas injetáveis. J Bras Psiquiatr. 2002;51:323-6.

6. Pechansky F, Von DL, Inciardi JA, Surratt H, De BR. Risk factors for HIV transmission in drug users from Porto Alegre, Rio Grande do Sul State, Brazil. Cad Saude Publica. 2004;20(6):1651-60.

7. Lowry R, Holtzman D, Truman BI, Kann L, Collins JL, Kolbe LJ. Substance use and HIV-related sexual behaviors among US high school students: are they related? Am J Public Health. 1994;84 (7):1116-20.

8. Donenberg GR, Pao M. Youths and HIV/AIDS: psychiatry's role in a changing epidemic. J Am Acad Child Adolesc Psychiatry. 2005;44(8):728-47.

9. Obermeyer CM, Osborn M. The utilization of testing and counseling for HIV: a review of the social and behavioral evidence. Am J Public Health. 2007;97(10):1762-74

10. Stein JA, Nyamathi A. Gender differences in behavioural and psychosocial predictors of HIV testing and return for test result in a high-risk population. AIDS Care. 2000;12(3):343-56.

11. Murphy DA, Mitchell R, Vermund SH, Futterman D; Adolescent Medicine HIV/AIDS Research Network. Factors associated with HIV testing among
HIV-positive and HIV-negative high-risk adolescents: the REACH Study. Reaching for Excellence in Adolescent Care and Health. Pediatrics. 2002;110(3):e36.

12. Metzger DS. The Risk Assessment Battery (RAB): validity and reliability. Alexandria: National Institute of Allergy and Infectious Diseases; 1993.

13. Pechansky F, Hirakata V, Metzger DS. Adaptation and validation of a questionnaire about risk behaviours for AIDS among drug users. Rev Bras Psiquiatr. 2002;24(3):130-6.

14. Caballero HR, Villasenor SA. Socioeconomic strata as a predictor factor for constant condom use among adolescents. Rev Saude Publica. 2001;35(6):531-8.

15. Whaley AL. Preventing the high-risk sexual behavior of adolescents: focus on HIV/AIDS transmission, unintended pregnancy, or both? J Adolesc Health. 1999;24(6):376-82.

16. UNAIDS, Monitorating the commitment on HIV/AIDS - Guidelines on the construction of Core indicators - 2010 reporting. [cited 2010 Apr 12]. Available from: http://data.unaids.org/pub/Manual/2009/ JC1676_Core_Indicators_2009_en.pdf

17. Report on the global AIDS Epidemic / Executive summary. UNAIDS, 2008. [cited 2010 Apr 12]. Available from:http://data.unaids.org/pub/ GlobalReport/2008/JC1511_GR08_ExecutiveSummary_en.pdf

18. Wingood GM, DiClemente RJ, Harrington KF, Lang DL, Davies SL, Hook EW, Oh MK, Hardin JW. Efficacy of an HIV prevention program among female adolescents experiencing gender-based violence. $\mathrm{Am} \mathrm{J}$ Public Health. 2006;96(6):1085-90.

19. Schraiber Lilia B Lima, D’Oliveira Ana Flávia P L, França Junior Ivan. Violência sexual por parceiro íntimo entre homens e mulheres no Brasil urbano, 2005. Rev. Saúde Pública [periódico na Internet]. [citado 22 Nov 2009]. Disponível em: http:// www.scielo.br/scielo.php?script=sci_ arttext\&pid=S0034-89102008000800015\&lng=pt. doi: $10.1590 /$ S0034-89102008000800015. 
20. Newcomb MD, Locke TF, Goodyear RK. Childhood experiences and psychosocial influences on HIV risk among adolescent Latinas in southern California. Cultur Divers Ethnic Minor Psychol. 2003;9(3):219-35.

21. WHO - World Health Organization. Complications of abortion: technical and managerial guidelines for prevention and treatment. Geneva: World Health Organization; 1995.

22. Olinto MT, Moreira-Filho DC. Risk factors and predictors of induced abortion: a population-based study. Cad Saude Publica. 2006;22(2):365-75.

23. Hein K, Dell R, Futterman D, Rotheram-Borus MJ, Shaffer N. Comparison of HIV+ and HIV-adolescents: risk factors and psychosocial determinants. Pediatrics. 1995;95(1):96-104.

24. Béria J, Oliveira OMF, Carret MLV. Ficar, transar...: a sexualidade do adolescente em tempos de AIDS. Porto Alegre: Tomo Editorial; 1998.

25. Carlini E, Galduroz JCF, Noto AR, Nappo SA. I levantamento domiciliar sobre o uso de drogas psicotrópicas no Brasil: estudo envolvendo as 107 maiores cidades do pais. São Paulo: CEBRID: UNIFESP; 2002.

26. Chaisson RE, Bacchetti P, Brodie B, Sande MA, Moss AR. Cocaine use and HIV infection in intravenous drug users in San Francisco. JAMA. 1989;261(4):581-5.

27. Schoenbaum EE, Hartel D, Selwyn PA, Klein RS, Davenny K, Rogers M, Feiner C, Friedland G. Risk factors for human defficience virus infection in intravenous drug users. New Engl J Med. 1989;321(13):874-9.

28. Vlahov D, Munoz A, Anthony JC, Cohn S, Celentano DD, Nelson KE. Association of drug injection patterns with antibody to human immunodeficiency virus type 1 among intravenous drug users in Baltimore, Maryland. Am J Epidemiol. 1990;132(5):847-56.

29. Pechansky F, Von DL, Kessler F, De BR, Surrat H, Inciardi J. Predictors of HIV seropositive status in non-IV drug users at testing and counseling centers in Porto Alegre, Rio Grande do Sul, Brazil. Cad Saude Publica. 2005;21(1):266-74.

30. Tucker JS, Wenzel SL, Elliott MN, Marshall GN, Williamson S. Interpersonal violence, substance use, and HIV-related behavior and cognitions: a prospective study of impoverished women in Los Angeles County. AIDS Behav. 2004;8(4):463-74.

31. Von Diemen L, De Boni R, Kessler F, Benzano D, Pechansky F. Risk behaviors for HCV- and HIV-seroprevalence among female crack users in Porto Alegre, Brazil. Arch Womens Ment Health. 2010;13(3):185-91.

32. Inciardi JA, Surratt HL, Pechansky F, Kessler F, von Diemen L, da Silva EM, Martin SS. Changing patterns of cocaine use and hiv risks in the south of Brazil. J Psychoactive Drugs. 2006;38(3):305-10.

33. Pechansky F, Woody G, Inciardi J, Surratt H, Kessler F, Von Diemen L, Bumaguin DB. HIV seroprevalence among drug users: an analysis of selected variables based on 10 years of data collection in Porto Alegre, Brazil. Drug Alcohol Depend. 2006;82 Suppl 1:S109-13.

34. Pechansky F, Kessler F, Von Diemen L, Inciardi JA, Surratt H. Substance use, risk situations, and HIV seroprevalence among individuals seeking free HIV testing in Porto Alegre, Brazil. Rev Panam Salud Publica. 2005;18(4-5):249-55.

35. Pechansky F, von Diemen L, Kessler F, Hirakata V, Metzger D, Woody GE.Preliminary estimates of human immunodeficiency virus prevalence and incidence among cocaine abusers of Porto Alegre, Brazil. J Urban Health. 2003;80(1):115-26.

36. Pechansky F, Halpern SC, Soibelman M, Bicca C, Szobot CM, da Silva Lima AF, Shiba AS. Limitations and alternatives to the implementation of a program for drug users at risk of HIV infection using the Social Network Approach. Cad Saude Publica. 2001;17(1):195-204. 